\title{
The Impact of Pakistani and Chinese Cultural Differences on Project Success in Chinese Project Oriented Companies
}

\author{
Shahzad Naeem ${ }^{1 *}$, Kamran Butt ${ }^{1}$ and Benish Khanzada ${ }^{2}$ \\ ${ }^{1}$ Riphah International University, Islamabad, Pakistan \\ ${ }^{2}$ Faculty of Quetta Institute of Medical Sciences, National University of Medical Sciences (NUMS), Pakistan
}

\begin{abstract}
Project Managers have multidimensional responsibilities that ominously have impact of the success of the Project. In this study, has been conducted to judge the impact of Cultural differences on the Project success especially in Pakistani and Chinese contexts through mediating role of Managerial actions. The data were collected from 103 respondents, who are employees of 04 Multinational Telecom Vendors/operators. This study provides a new though to researchers to further explore the impact of Pakistani and Chinese Cultural differences on Project Success.
\end{abstract}

\section{Keywords: Project success; Pakistan-China cultural differences}

\section{Introduction}

The Culture can be described as the Collective Programming of mind of larger group of individuals and in this article we will imperially explore the Impact of Chinese and Pakistani Cultural Diversity on project Success through Managerial Actions. As the Cultures have significant impacts on the projects [1]. Hence, the creative organizational culture has a creative role in the organization [2]. As, here the Chinese and Pakistani Cultural Diversity is being studied because of China's increasing business in Pakistan and highly context and rich Chinese Cultural values [3]. The Chinese Companies like Huawei and ZTE etc. are paying special attention towards HR practices while operating in South Asian countries [4]. At one side, the China has a highly context culture which needs to be deeply comprehended while, Pakistan can be termed as a highly collectivist Society [5], therefore, exhaustive study and understanding of Chinese culture is required to interact with Chinese professionals [6]. Another apposite element for such studies in that mostly cultural studies conducted in US etc. Sometimes show different results in Chinese Context and on the other side, the Researches in Chinese context have a special significance as their studies are commonly not applicable globally [7].

The professional engaged in deployment of Sino-Pak Project Organizations need to deeply understand this diversity. They can better manage the teams by keenly observing the cultural differences and enhance their learning from the social environment [8]. If the Managers are well aware of the Cultural matters and ensure the effective communication with teams, they will be able to manage the teams in most effective manner and the positive results will be obtained through efficiently integrated teams and this behavioral control will result in good governance [9-11]. Furthermore, the teams harmony and joint positive working improves the overall learning [12], the positive contributions from each team member will contribute to minimize the communication gap and this partnership will ensure the positive results $[13,14]$. Wiewiora et al. [15] advocate that some cultural ethics have positive impact on knowledge sharing among members of diverse teams and being an Islamic Country, the majority of staff serving in organizations are Muslim, so their Islamic Work Ethics will also play the moderating role to improve the performance [16]. The China has potential to globally take over the American economy in next few years and in Pakistan also numerous mage projects will be implemented in coming future by China.

Since 1951, China has always been the most trustable and supportive friend of Pakistan and this Sino-Pak Friendship has been passed through numerous difficult and tough times. The development in defense sector, advancement in technological grounds, building of infrastructure, Progression in Telecom Sector and many other economic developments were only possible with the social, economic and financial assistance of the People's Republic of China. In recent past, numerous mega projects have been successfully implemented by Chinese Companies in Pakistan, which were the result of mutual team work and understanding. Recently, during the meeting of the heads of both states, many contracts on mega-projects were signed especially for power generation, including $660 \mathrm{MW}$ Muzaffargarh coal-fired Power project, $660 \mathrm{MW}$ Sahiwal coal-fired Power Project, Hydro Power Project at Suki-Kinari, 330 MW Thar coal-fired Plant, 99 MW UEP Power Project and 900 MW Quad-e-Azam Solar Power Projects.

Significantly, Pakistan-China have recently agreed for implementation of the CPEC (China-Pakistan Economic Corridor) Projects, which can be termed as the regional economic integration beyond the geographical route; it represents the domestic institutional arrangements and macro-economic coordination between Pakistan and China. The CPEC will be a network of 3,000 KM Roads, Railways and Pipelines for Transportation of Oil and Gas from Gawadar to Kashgar City, Northwestern China.

By implementation of above-mentioned Mega Projects, we may expect that many China based organization/companies will be extensively operating in Pakistan and it will be quite suitable to study the success factors and managerial actions in Pakistani-Chinese Cultural Context. The "Guan Xi" (Relationship building and mutual understanding) concept of chines culture also supports to understand each other to perform the better output by minimizing the conflicts and maximizing the stakeholder's satisfaction.

*Corresponding author: Shahzad Naeem, Riphah International University, Islamabad, Pakistan, Tel: 00923335491914; E-mail: shahzadflyer@yahoo.com

Received February 19, 2018; Accepted March 14, 2018; Published March 21, 2018

Citation: Naeem S, Butt K, Khanzada B (2018) The Impact of Pakistani and Chinese Cultural Differences on Project Success in Chinese Project Oriented Companies. J Bus Fin Aff 7: 323. doi: 10.4172/2167-0234.1000323

Copyright: $\odot 2018$ Naeem S, et al. This is an open-access article distributed under the terms of the Creative Commons Attribution License, which permits unrestricted use, distribution, and reproduction in any medium, provided the original author and source are credited. 


\section{Literature Review}

\section{Diversity}

The today's organizations are accepting and adopting the diversity in the workplace as essential business tools. This is because businesses are gradually beginning to recognize that their potential to achieve better results is increased when people from diverse backgrounds and perspectives are included at different levels of the organization, including in the decision-making process [17].

\section{Project success}

It seems not feasible to define the typical project success factors but it's the matter of what dimensions represent the project success but generally it can be communication, coordination, stakeholders, objectives, cost, budget, final product, acceptance, environment and risks etc. [18] and some other factors may also be included to represent the project success like Timely completion, PM's competencies and focus, strategic benefits and Top management's commitment etc. [19].

\section{Diversity and managerial actions}

Although each culture has its specific values, norms and patterns but some basic values are generally taken as common benchmarks that people believe to be valuable and important. i.e., Physical and mental health, subjective well-being, longevity and preservation of the natural environment. Although no culture be said to be a perfect one but cultures that obey and respect for these values can be said to be successful. When People from various cultures interact each other or enter into some activity where they have to work together, then they also have some common goals and objectives. Employees approach towards work are affected by their cultural values and even some Religious ethics also have significant impact on some peoples work attitudes these Values and norms have significant impacts on attitudes of people [20-22]. Like Some cultural norms promote to learning and adopting diversity, some culture believe in harmony and faithfulness among the people and such practice develop the trust among teams and it creates overall better working environment and overall harmony within the organization results in better employee commitment towards objectives achievement $[17,23,24]$.

Although there has been done a lot of work about managing and understanding the diversified team but still there is a lot to be done to understand social economic and cultural matters. Still there is a challenge between environment and business [25]. Christina et al. indicated that as diversified teams have variety of characteristics in many projects and Diversity can also have its impacts even at Senior Management Level [26,27], Therefore Managing diversified teams requires managers to be extra ordinarily capable of understanding cultures as diversity is relatively a complicated factor [28].

\section{Hypothesis-1}

H1: Cultural Diversity have impact on the managerial actions.

\section{Managerial actions contribute to project performance/success}

Understanding of culture is mandatory success factor for better communication and management [29]. Cultural awareness supports employees to better adjust in diversified teams and also managers who have good knowledge of cultures can better contribute to project success [30]. Managers understanding of cultures are also sometimes related with objective [31]. By understanding the cultural values and through conduction of cross-cultural interaction and understanding activities, Managers can improve the team member's affiliation to their organization by a various interactive action [32]. Such understanding of other cultures can create a Favorable job environment which may have positive impact on employee's satisfaction [33]. In the same way, if the HR practices are also aligned to understand diversity than such better HR practices can help to better utilize the diversified teams [34]. As in each organization Employees have much expectations to their leaders and effectiveness of their Leadership has impact even on innovations, so it will be a good opportunity for local employees to learn from expats. Furthermore, as managerial action are reflected in HR practices also than employees behaviors will be improved towards duties, Project Management performance effects the Success [35-38]. Managerial actions and traits have significant impact on project success [39].

\section{Hypothesis-2}

$\mathrm{H} 2$ : Managers have to understand diversity for better managing the teams.

\section{Culturally diversified teams enhance the chances of learning and project success}

Some people like new experiments and innovations [40] and even Expatriates servings in MNCs are eager to learn other culture's etc. [41], even Learning in project-based organizations may affect many outcomes [42]. In view of above, the Cultural trainings will definitely have some impact on employee's self-efficiency towards assigned tasks [43] and it's also understood that Diversity managed in better way improves performance [44]. As the Manager's motives can affect the employees and managers direct relations and may also affect performance, so if the managers succeed to create the harmony amongst teams they can get better results and If there is no harmony among teams, it may result in lower business, hence harmony among teams is necessary for better outcomes $[45,46]$.

Clear and well-coordinated processes have favorable impacts and virtuous HR Practices lead to better performance but also it related to managerial actions, so the managers need to be careful about understanding different team's members and their caring attitude will be positively perceived by team members [47-49]. Its prerequisite for Managers to minimize the conflicts among teams and build their mutual trust and this trust can also be associated with better team's establishment and working in such teams can results in mutual understanding and learning [50,51].

\section{Hypothesis-3}

H3: Pakistani and Chinese diversified teams have positive impact for learning and Project success.

\section{Cultural diversity contributes to success through managerial actions}

Multinational Companies operating in various countries try to adopt the local ways and respect for norms and values to better adjust therein [52] and in the same manner the Chinese Project based companies in Pakistan give much weightage to cultural values [53]. Chinese believe that Lack of synchronization may result in low efficiency and vice versa [54] and diversity can be taught and learnt at any level of employees [55] and Teams members diversity can moderate the performance [56], therefore, mostly Chinese adopt the "GuanXi" (relationship building) approach to have informal relations with the team members and project stakeholders [57]. The "GuanXi" approach is a belief that Better relationing can be an additive to success and even 
Citation: Naeem S, Butt K, Khanzada B (2018) The Impact of Pakistani and Chinese Cultural Differences on Project Success in Chinese Project Oriented Companies. J Bus Fin Aff 7: 323. doi: 10.4172/2167-0234.1000323

Page 3 of 6

in China, some Chinese traditions are now also being converted from only ethical practices to professional and business actions/practices and they also have started Transformation of the traditional HR systems and approaches to modern ones [58-60].

\section{Hypothesis-4}

H4: Pak-China Cultural diversity positively impacts on Projects success through better and enhanced Managerial actions.

\section{Methodology}

\section{Instrument}

This study was conducted by using a Questionnaire adopted from an Article by Kuen et al. [61], and MBA Thesis of Bovana [62]. The Questionnaire had 36 Items with Lickert's scale, 8 Items to measure the Diversity, 17 for Managerial Actions and 11 for Project Success. The data were collected in November-December 2016 on Cross Sectional basis. Some respondents were also sent Questionnaire through e-mails but the response rate was extra-ordinarily low. The Questionnaire was also submitted to some Chinese officers of various ranks and the response was taken by mutual discussion with them.

\section{Population and sample}

This study was conducted primarily within the Chinese Project based organizations operating in Pakistan and initially the selected population consisted of four mega Telecom Operators/Vendors. Due to limitation of Time period, convenience sampling method was adopted.

The data were collected from 260 Pakistani and Chinese Telecom Professionals serving in 04 Telecom Companies, with a response rate of 40 percent. Out of 04 organizations, 02 are China based Multi-
National Telecom Vendors, 01 China Based Multi-national Telecom Operator and 01 is the organization, which has awarded their contracts to Chinese Companies for execution. 75\% respondents are Managers or above level officers, 77\% Males and 33\% Females, more than 98\% respondents are graduates or above, $85 \%$ Pakistani and 15\% Chinese Nationals. $55 \%$ of respondent's age is between 26 to 40 Years, $22 \%$ from 40 to 50 years and $2 \%$ Above 50 years. Regarding the professional experience of respondents, $11 \%$ have professional experience of less than 3 years, 18\% have $4 \sim 5$ Years' experience, $42 \%$ have $6 \sim 10$ Years and $29 \%$ have experience of more than 10 years.

\section{Results}

Means, Standard Deviations and Correlations among the variables are shown in the Table 1 while the Table 2 represents the regression Analysis to analyze the effect of Pak-China Cultural Diversity of Project Success through Managerial Actions. Baron \& Kenny's Method was used to test the Step- Wise Mediation Analysis. Path 'A' and Path 'B' show the significance but the test on Path 'C' (IV to DV) shows no significance, hence the mediation cannot be tested (Tables 1 and 2).

Results indicate that Cultural Diversity has significant impact on managerial actions and managers have to adopt such actions which may cater the diversity issues and even mold the diversity into positive and productive approaches which supports our Hypothesis-I. This also supports the findings of past studies which confirm the impact of cultural diversity on Manager's actions and ways of managing the things [28].

It was also found that when there are diversified teams than Mangers have to understand them better to manage them better. Simply, clearly understanding of a matter may result in better handling and solution of

\begin{tabular}{|c|c|c|c|c|c|c|c|c|c|c|c|c|}
\hline S. No & Variable & Mean & $\begin{array}{l}\text { Std. } \\
\text { Deviation }\end{array}$ & 1 & 2 & 3 & 4 & 5 & 6 & 7 & 8 & 9 \\
\hline 1 & Organization & 2.41 & 0.994 & & & & & & & & & \\
\hline 2 & Designation & 2.97 & 0.944 & 0.044 & & & & & & & & \\
\hline 3 & Gender & 1.24 & 0.431 & 0.133 & -0.175 & & & & & & & \\
\hline 4 & Age & 3.63 & 1.120 & 0.101 & $0.778^{* *}$ & $-0.321^{* *}$ & & & & & & \\
\hline 5 & Education & 2.74 & 0.656 & -0.150 & $0.557^{* *}$ & -0.120 & $0.481^{\star *}$ & & & & & \\
\hline 6 & Experience & 3.90 & 0.945 & -0.114 & $0.744^{\star *}$ & $-0.351^{* *}$ & $0.827^{* *}$ & $0.480^{* *}$ & & & & \\
\hline 7 & Diversity & 3.5983 & 0.72013 & $0.200^{*}$ & 0.055 & -0.165 & -0.135 & -0.147 & -0.153 & $(0.877)$ & & \\
\hline 8 & Managerial Actions & 3.3524 & 0.43683 & 0.032 & $0.249^{*}$ & 0.053 & -0.013 & -0.017 & 0.075 & $0.361^{\star *}$ & $(0.755)$ & \\
\hline 9 & Project Success & 3.1218 & 0.50175 & -0.113 & -0.002 & 0.179 & $-0.213^{*}$ & -0.051 & -0.123 & 0.023 & $0.533^{* *}$ & $(0.715)$ \\
\hline \multicolumn{13}{|c|}{$\begin{array}{l}{ }^{*} \text { Correlation is significant at the } 0.05 \text { level (2-tailed). } \\
{ }^{* *} \text { Correlation is significant at the } 0.01 \text { level (2-tailed). } \\
\text { Alpha Reliability of each variable is shown in parenthesis (). } \\
\text { Total sample size, } n=103 \text {. }\end{array}$} \\
\hline
\end{tabular}

Table 1: Descriptive statistics and correlation

\begin{tabular}{|c|c|c|c|c|c|c|}
\hline \multirow[t]{2}{*}{ Predictors } & \multicolumn{3}{|c|}{ (Med.) MA } & \multicolumn{3}{|c|}{ (DV2) PS } \\
\hline & $\beta$ & $\mathrm{R}^{2}$ & $\Delta \mathrm{R}^{2}$ & $\beta$ & $\mathrm{R}^{2}$ & $\Delta \mathrm{R}^{2}$ \\
\hline \multicolumn{7}{|l|}{ Main Effect: CD } \\
\hline \multicolumn{7}{|l|}{ Step I: } \\
\hline Control Variables & & 0.447 & & & 0.364 & \\
\hline \multicolumn{7}{|l|}{ Step II: } \\
\hline CD & $0.185^{\star * *}$ & 0.518 & $0.059^{\star * *}$ & $\ldots .028$ & 0.365 & 0.001 \\
\hline MA & & & & $0.602^{* * *}$ & 0.594 & $0.220^{* * *}$ \\
\hline
\end{tabular}

${ }^{* * *} p \leq 0.000$.

CD: Cultural Diversity; MA: Managerial Action; PS: Project Success.

Control Variables for MA are organization, position, gender, age, education and experience.

Control Variables for PS organization, position, gender, age, education and experience.

Table 2: Hierarchical/Mediation regression analysis. 
the issue. Hence, the results also support Hypothesis-II that Managers have to understand diversity to better manage their team's and it may result in better project outcomes [39].

Table 2 indicate that Pakistani and Chinese Cultural Diversity has no significant impact on Project success and hence the Hypothesis-III and IV and Rejected. For such results, the managers and senior level officers from sample population were contacted to discuss the reason and they have suggested that it might be due to a variety of factors i.e., Highly Complexity of Chinese Culture, Highly Collectivistic Pakistani Cultural Traits, Pakistani People's perception about Chinese products and about the Chinese Companies, The Low-Cost strategy of Chinese Organizations, Inadequate Salaries and fringe Benefits in comparison to other Multi-national Companies, the overall popularity and image of our political leaders and governments impact on businesses, people's variety of expectations and conceptions about China-Pak Economic Corridor Projects, Media's role in creating the image of up-coming mega projects and our political \& industry leaders statements about near future's mega projects.

\section{Discussion}

The outcomes of this study have some management repercussions, the Cultural Diversity and its impacts on Managerial actions cannot be divorced because Managers have to be vigilant about the diversity and the matters related to diversity. Managers need to mold the diversity features into productive practices to create harmony and cooperation amongst their teams. This study hereby confirms the positive impact of diversity amongst the team members which results in mutual harmony and learnings and confirms the studies by Tachia [24]

This study indorses that Managers may understand the diversity to better manage their teams and be aware of their employee's behaviors etc. The better understanding of employees can result in their better management and performance [33]. Furthermore, manager's performance collectively impacts the project success so the organizations have started spending huge amounts in training and development of their staff to overcome the cultural diversity and teams management issues.

Regarding the least impact of Pakistani and Chinese Cultural Diversity on the Project Success, we discussed the results with few senior Management Level officers and Mangers and tried to sort out the factors which can support this concept. The feedback from concerned managers and officers was interesting because they have indicated numerous factors which have resulted in a specific Mind-set of our people and may be these are the reasons behind the low or less impact of diversity on project success. In Pakistan, majority of people have a concept of Chinese Low-cost strategy throughout in their companies' operations and the same is adopted for their HR policies, employees when not paid adequately, do not sometimes do not even care whether they are serving with Pakistani or Chinese Bosses. Even, our media has also created a strange impression of upcoming mega projects especially they are trying to create a sort of controversy about CPEC so this cultural diversity may have unclear impacts of the projects.

\section{Limitations}

\section{Population and sampling}

Due to limitation of time, only few Chinese Project based organizations were selected for collecting data about this study. At present, numerous Chinese companies are operating in Pakistan and the results could be more accurate and comprehensive, if the larger population was targeted. The date were collected from only 103 respondents which may not be true representative of thousands of officers and managers serving in such project based organizations, so in future if such study is conducted, the sample size would be larger.

Limitation of time and lack of funds for study resulted in convenience sampling and it is recommended that future studies would be conducted with some more reliable and authentic sampling method.

\section{Data collection}

Cross sectional data were collected as the total time period available was around two months for Questionnaire finalization, Testing and Data collection. Hence, the results can be more appropriate if date is collected on time lapse basis.

\section{Research model}

The simple research model with only one IV and one mediator was studied, it is suggested that in future the researchers may study more variables and factor effecting project success.

\section{Conclusion}

As China has the potential to dominate the global economies in coming few years and even in Pakistan the Pakistani and Chinese collaborations for mega projects implementation has an historic track record. For upcoming Energy and infrastructure gigantic projects, understanding the cultural differences and traits of diversified work force is mandatory for Managers and an emerging challenge for the organizations. Although, this study has not proved or could not collect significant evidences of Pak-China Cultural difference massive impact on the project success but its suggested that there is so much yet to be explored due to high complexity of Pakistani and Chinese Culture, their rich values and traditions, the popular hospitality of Pakistanis and slow and steady invasion of Chinese in the Global economies.

\section{References}

1. Friesel M, Sackmann SA, Kremser S (2011) Knowledge sharing in new organizational entries: The impact of hierarchy, organizational context, micropolitics and suspicion. Cross Cultural Management: An International Journal 18: 71-86.

2. Bock AJ, Opsahl T, George G, Gann D (2011) The effects of culture and structure on strategic flexibility during business model innovation. Journal of Management Studies 49: 44

3. Fang T (2010) Asian management research needs more self-confidence: Reflection on Hofstede (2007) and beyond. Asia Pacific Journal of Management 27: 155-170.

4. Cooke FL (2014) Chinese multinational firms in Asia and Africa: Relationships with institutional actors and patterns of HRM practices. Human Resource Management 53: 877-896.

5. Bashir S, Nasir M (2013) Breach of psychological contract, organizational cynicism and union commitment: A study of hospitality industry in Pakistan. International Journal of Hospitality Management 34: 61-65.

6. Li PP, Leung K, Chen CC, Luo JD (2012) Indigenous research on Chinese management: What and how. Management and Organization Review 8: 7-24.

7. Leung K (2012) Editorial, Indigenous Chinese management research, like it or not, we need it. Management and Organization Review 8: 1-5.

8. Chipulu M, Ojiako U, Paul G, Williams T, Mota C, et al. (2014) Exploring the impact of cultural values on project performance-The effect of cultural values age and gender on the perceived importance of project success/failure factors. International Journal of Operations \& Production Management 34: 364-389.

9. Wilkinson A, Dundon T, Donaghey J, Townsend K (2014) Partnership, collaboration and mutual gains: Evaluating context, interests and legitimacy. International Journal of Human Resource Management 25: 737-747. 
Citation: Naeem S, Butt K, Khanzada B (2018) The Impact of Pakistani and Chinese Cultural Differences on Project Success in Chinese Project Oriented Companies. J Bus Fin Aff 7: 323. doi: 10.4172/2167-0234.1000323

Page 5 of 6

10. Ahmad S, Mallick DN, Schroeder G (2013) New product development: Impact of project characteristics and development practices on performance. Journal of Product Innovation Management 30: 331-348.

11. Joslin R, Muller R (2016) The relationship between project governance and project success. International Journal of Project Management 34: 613-626.

12. Bartsch V, Ebers M, Maurer I (2013) Learning in project-based Organizations: The role of project teams' social capital for overcoming barriers to learning. International Journal of Project Management 31: 239-251.

13. Glover L, Tregaskis O, Butler P (2013) Mutual gains? The workers' verdict: A longitudinal study. International Journal of Human Resource Management 25 895-914.

14. Valizade D, Ogbonnaya C, Tregaskis O, Forde C (2016) A mutual gains perspective on workplace partnership: Employee outcomes and the mediating role of the employment relations climate. Human Resource Management Journal.

15. Wiewiora A, Murphy G, Trigunarsyyah B, Brown K (2014) Interactions between organizational culture, trustworthiness, and mechanism for inter-project knowledge sharing. International Journal of Project Management 45: 48-65.

16. Khan AS, Rasheed $F$ (2014) Human resource management practices and project success, a moderating role of Islamic work ethics in Pakistani projectbased organizations. International Journal of Project Management 33: 1-11.

17. Carvell NM, Paula AC (2015) A context-specific model of organizational trust: an examination of cognitive and socio-affective trust determinants in unique cultural settings. Cross Cultural Management 22: 297-320.

18. Gabriella C, Lajos S (2013) The relationship between success criteria \& success factors in organizational event projects. International Journal of Project Management.

19. Kate D (2014) Different stakeholder groups and their perception of project success. International Journal of Project Management 32: 189-201.

20. Mary CK, Sharon W, Fang FC, Tai GK (2011) How cultural values affect the impact of abusive supervision on worker attitudes. Cross Cultural Management: An International Journal 18: 464-484.

21. Michael M, Michael HB, Vesselin B (2015) Do different national samples yield similar dimensions of national culture? Cross Cultural Management 22: 259277.

22. Cristina LD, Marta M, Vidal SB, González D (2015) Impact of cultural positions on FDI's entry mode. Cross Cultural Management 22: 509-526.

23. Hilla P, Ariel L, Yitzhak F (2015) Organizational diversity programs across cultures: Effects on absenteeism, turnover, performance and innovation. The International Journal of Human Resource Management 26: 875-903.

24. Tachia C (2014) Harmony as means to enhance affective commitment in a Chinese organization. Cross Cultural Management 21: 326-344.

25. Walls JL, Triandis HC (2014) Universal truths: Can universally held cultural values inform the modern corporation. Cross Cultural Management 21: 345356

26. Christina K, John C, Warren P (2012) The impact of cross cultural dynamics on change management. Cross Cultural Management: An International Journal 19: 166-195.

27. Joana M, Janneke P, Chantal R (2015) Gender diversity and firm performance: Evidence from Dutch and Danish boardrooms. The International Journal of Human Resource Management 27: 1777-1790.

28. Fernando MA, Pedro MRF, Gonzalo SG (2013) Workforce diversity in strategic human resource management models. Cross Cultural Management: An International Journal 20: 39-49.

29. Armando C, Guendalina C, Francesca DP, Federico M (2014) Cultura adaptation of web design services as critical success factor for business excellence. Cross Cultural Management 21: 172-190.

30. Jeevan J, Sumeet K (2015) Assessing the cultural intelligence and task performance equation: Mediating role of cultural adjustment. Cross Cultural Management: An International Journal 22: 236-258.

31. Goudarz A (2014) How congruent are manager's perceptions of cultural distance with objective reality? Cross Cultural Management 21: 400-421.

32. Jung N, Chang C, Yi C (2015) Effects of learning orientation \& team embeddedness on mobility. Cross Cultural Management 22: 570-593.

33. Jeanine KA, Lawter L, Brocker H, Peter JR (2014) Cultural impact of human resource practices on job satisfaction. Cross Cultural Management 21: 55-77.

34. Islam G (2013) Recognizing employees: Reification, dignity and promoting care in management. Cross Cultural Management: An International Journal 20: 235250 .

35. Sylvie G, Julie S, Doina M (2013) Pro-diversity practices and perceived insider status. Cross Cultural Management: An International Journal 20: 5-19.

36. Ignacio GV, Justin JPJ, Frans AJ, Volberda HW (2012) Management innovation and leadership: The moderating role of organizational Size. Journal of Management Studies 49: 1.

37. Alfes K, Shantz AD, Truss C, Soane EC (2013) The link between perceived human resource management practices, engagement and employee behaviour: A moderated mediation model. The International Journal of Human Resource Management 24: 1-22

38. Farzana AM, Ashly P (2014) Exploring the value of project management: Linking project management performance and project success. International Journal of Project Management 32: 202-217.

39. Riza YS (2015) Project manager skills for improving project Performance. International Journal of Business Performance Management 16: 67-83.

40. Gert JH (2015) Culture's causes: the next challenge. Cross Cultura Management 22: 545-569.

41. Christian Y (2014) The impact of cultural dimensions on Chinese expatriate's career capital. The International Journal of Human Resource Management 25 609-630.

42. Vera B, Mark E, Indre M (2013) Learning in project-based organizations: The role of project team's social capital for overcoming barriers to learning. International Journal of Project Management 31: 239-251.

43. Michael TR, Michael JG, Reza AG (2012) Examining the influence of crosscultural training on cultural intelligence and specific self-efficacy. Cross Cultura Management: An International Journal, 19:2, 215-232.

44. Orlando CR, Weichieh S, Mike WP, Carliss DM (2014) Do external diversity practices boost focal firm performance? The case of supplier diversity. The International Journal of Human Resource Management 26: 2227-2247.

45. Gould-Williams JS (2016) Manager's motives for investing in HR practices \& their implications for public service motivation: A theoretical perspective. International Journal of Manpower 37: 764-776.

46. Stephan B, Uwe B (2014) Effects of cultural diversity on individual establishments. International Journal of Manpower 35: 166-186.

47. Xianhai M (2012) The effect of relationship management on project performance in construction. International Journal of Project Management 30: 188-198.

48. Rebecca RK, Patrick MW (2013) Attitudes and behaviors: The impact of highperformance human resource practices on employees. Journal of Management 39: $366-391$

49. Kristine MK (2013) Understanding the concept of care in cross-cultural settings. Cross Cultural Management: An International Journal 20: 100-123.

50. Sepehr G, Ali B, Ardeshir L (2014) Social capital \& national innovation system A cross-country analysis. Cross Cultural Management 21: 453-475.

51. Stephen P, Zoe R (2016) Teamworking and lean revisited: A reply to Carter et al. The International Journal of Human Resource Management 28: 468-480.

52. Gilbert GR, Glinow MAV (2015) National context and organizational performance across three sectors. Cross Cultural Management 22: 356-378.

53. Ying L, Yuanjie B, Wei L (2013) Mapping the values and culture in Chinese public sectors: An exploratory study. Cross Cultural Management 20: 559-577.

54. Yaakov W, Shlomo UT (2012) Mergers and acquisitions process: The use of corporate culture analysis. Cross Cultural Management 9: 288-303.

55. Chandana S, Doirean W, Charlotte S, Jude SR, Satwant K, et al. (2015) Diversity and inclusion depend on effective engagement: It is everyone's business to ensure that progress is maintained. Human Resource Management International Digest 23: 21-24.

56. Merce M, Yehuda B (2015) Team performance in cross cultural project teams Cross Cultural Management 22: 464-486. 
Citation: Naeem S, Butt K, Khanzada B (2018) The Impact of Pakistani and Chinese Cultural Differences on Project Success in Chinese Project Oriented Companies. J Bus Fin Aff 7: 323. doi: 10.4172/2167-0234.1000323

57. Xiao PC, Marion BE, Ting-Ju C, Jiing LF, Bore BC (2014) Affective trust in Chinese leaders: Linking paternalistic leadership to employee performance. Journal of Management 4: 796-819.

58. Matin V, Alexander K (2013) Impact of relationship value on project portfolio success-Investigating the moderating effects of portfolio characteristics and external turbulence. International Journal of Project Management 31: 847-861.

59. Zheng X, Yochanan A (2015) The panacea of culture: The changing fortunes and careers of China's Dongba priests. Cross Cultural Management 22: 649660.
60. Zhong-Xing S, Patrick MW (2012) The effective human resource management system in transitional China: A hybrid of commitment and control practices. The International Journal of Human Resource Management 23: 2065-2086.

61. Kuen CW, Zailani S, Fernando $Y$ (2009) Critical factors influencing the project success amongst manufacturing companies in Malaysia. African Journal of Business Management 3: 16-27.

62. Bovana LP (2014) Assessing diversity management within the Western Cape Department of Community Safety (DCS). Stellenbosch University, South Africa. 